\title{
Study on Nutritional Nurses Knowledge Regarding Diabetes in Basra City Center Hospitals
}

\author{
Wasfi Dhahir Abid Ali", Ertihal Thamer Nasir and Abeer Bahlol Mohi \\ College of Nursing, University of Basrah, Iraq \\ *Corresponding author
}

\begin{tabular}{|c|}
\hline Keywords \\
\hline Nutrition, Diabetes \\
\hline Article Info \\
\hline $\begin{array}{l}\text { Accepted: } \\
16 \text { August } 2018 \\
\text { Available Online: } \\
\text { 10 September } 2018\end{array}$ \\
\hline
\end{tabular}

\section{A B S T R A C T}

Nurses play an important and critical role in educating the individual with diabetes. Aim of the study is to assess the knowledge level of nurses and associated factors in the nutritional management of diabetes with sample of 100 nurses in Basra hospitals; Closed - end questions questionnaire was used for the purpose of data collection. The results showed that nurses knowledge that concerning fatty food are about diabetes patient should not exclude any nutrient from their diet over (70\%) said diabetes patients not could exclude any of the major nutrients from their meals while (20\%) of them indicated that carbohydrates, proteins and fats respectively should be excluded from the meals. A large proportion of the nurses (95\%) could recognize that diabetes and obesity are closely related and found (99\%) of them could recognize exercise plays important role in the prevention and management of diabetes. Also found a large proportion of the nurses over (40\%) could recognize that diabetes is not caused by high sugar intake, and over (30\%) of nurses did not know the cholesterol should be restricted to (300) $\mathrm{mg}$ daily for diabetes patients. Also showed in this study over (40\%) of the nurses unable to identify there recommended daily caloric intake from carbohydrates for diabetes patients. And over (40\%) of the nurses could not correctly identify recommended fasting plasma glucose level for diabetes. The recent study also showed that level of education was (35\%) for BSC, on other hand female $(65 \%)$ were more than male. Even though the differences were not significant we found that higher knowledge scores were associated with nurses nursing Bachelors degree and those having worked for (5) years or lower.

\section{Introduction}

Nurses play an important and critical role in educating the individual with diabetes. Their role has become more pertinent in these recent times of the rising prevalence of diabetes (especially type 2 ) in every country.

Reports showed that 382 million people have diabetes and will rise to 592 million by the year 2035). It reports that $80 \%$ of People with diabetes live in low- and middle-income countries.

An estimated 522, 600 people in Sub-Saharan Africa died from diabetes-Related causes in 2013 (Aguiree et al., 2013). With a clinical feature of high blood Glucose, the major goal of diabetes treatment and management is to maintain normal or near normal blood glucose 
levels (Carney, 2010) in affected individuals it has been shown that maintaining normal or near Normal blood glucose levels in people with diabetes reduces complications (Nelms, Sucher et al., 2010). Diabetes care is largely self-care requiring the active participation of the patient. In decision making, goal setting and daily management processes (Sukhpal and Indarjit, 2007). Effective self-management care is provided by a multidisciplinary team of healthcare professionals including nurses, dieticians, Pharmacists, physicians, and diabetes educators. An important component of the self-management care is nutrition. Patients are usually educated on basic mean planning, carbohydrate counting and exchanges as well as how to read food labels with the goal of making them independent (Bantle et al., 2008). Although nutrition education is the responsibility of dieticians and/or nutritionist, nurses have an important role to play.

Patients are more likely to trust them and seek for advice from them regarding the treatment and management of their condition. A study from the US and Australia have reported that $90 \%$ of nurses routinely receive request for nutrition advice from patients the best of care (Lindseth, 1990). Nurses must be adequately knowledgeable about nutrition therapy for diabetes patients (Scheiderich et al., 1983; Evert et al., 2013) in order to provide effective advice.

\section{Materials and Methods}

This study was across- sectional and multicenter involving (100) nurses regarding diabetes of three hospitals nurses in Basrah city center. To achieve the aim of the study, questionnaire was designed and translated to Arabic language, and it divided in to Main parts, the first part was to identify the sociodemographic characteristics and Second part was to identify the nutritional nurses knowledge regarding the Diabetes. The project carried out in the Basrah hospitals. The study started from tenth October (2017) to one first April (2018). Statistical data analysis includepercentage, frequency and mean of score by SPSS (Statistical package for social sciences) program for find the outcome.

\section{Results and Discussion}

Although nutrition education for diabetes patients is the responsibility of dieticians and nutritionist, nurses played an important role.In this study the knowledge levels of nurses and associated factors in the nutritional management of diabetes were measured.

The recent study female and the higher knowledge percentage were associated with nurses having Bachelor's degree (53\%). And those having worked for (5) years or lower $(71 \%)$. showed that the groups that have been the distribution of questioners where $(35 \%)$ working in other sites, (30\%) working in Internal medicine, $(25 \%)$ working in Surgery and $(10 \%)$ working in Neurology. Furthermore nurses who took one nutrition courses and work in the other sites $(77 \%)$. Nursing programmers with regards to nutrition could help improve the nutrition knowledge of nurses during training. These findings also indicate that making refresher courses available to nurses may help improve their knowledge in the nutritional management of diabetes (Victor et al., 2015; Warber et al., 2000).

Showed significant nursing knowledge that concerning fatty food about diabetes, patient should not exclude any nutrient from their diet more evidently, about (10\%) of the nurses did not know that it is important for diabetes patients to eat balanced diets as $(20 \%)$ of them indicated that carbohydrates, protein and fats respectively should be excluded from the meals of diabetes patient. 
Also the study showed that nurses knowledge on the average amount of the calories expected from carbohydrates to be of the weakest. Over $(30 \%)$ of them indicated that they did not have an idea at all as to the daily macronutrient requirements of diabetes patients while over (10\%) wrong options.

Furthermore, over (20\%) of the nurses did not know that the total amount of carbohydrates consumed per meal is generally more important than the type of carbohydrate consumed with over $(40 \%)$ of the nurses ever providing dietary advice to diabetic patients, these findings makes one to worry about the quality of advice provided to the diabetes patients. nurses in the dietary management of fats may pose risks to the adherence of the diabetes patients to dietary recommendations, Victor et al., (2015) found in their study a poor knowledge on nutritional management of diabetes (Table 1-5).

Table (1) Frequency and percentage of gender

\begin{tabular}{|l|l|l|l|}
\hline \multirow{4}{*}{ Gender } & Group & frequency & percentage \\
\cline { 2 - 4 } & male & 35 & $35 \%$ \\
\cline { 2 - 4 } & female & 65 & $65 \%$ \\
\cline { 2 - 4 } & Total & 100 & $100 \%$ \\
\hline
\end{tabular}

Table (2) Frequency and percentage of educational level

\begin{tabular}{|l|l|c|c|}
\hline \multirow{4}{*}{$\begin{array}{l}\text { Educational } \\
\text { level }\end{array}$} & Categories grouping & Frequency & Percentage \\
\cline { 2 - 4 } & Secondary nursing school & 26 & 26 \\
\cline { 2 - 4 } & Medical institute (Diplomate) & 26 & 26 \\
\cline { 2 - 4 } & Nursing college (Bachelor) & 53 & 53 \\
\cline { 2 - 4 } & High study(M.Sc. \& Ph.D. & 1 & 1 \\
\hline
\end{tabular}

Table(3) shoed year of experience

\begin{tabular}{|c|c|c|c|}
\hline \multirow{3}{*}{ Experience Years } & Categories/groupings & Frequency & Percent (\%) \\
\cline { 2 - 4 } & $5-1$ & 71 & $71 \%$ \\
\cline { 2 - 4 } & $10-6$ & 9 & $9 \%$ \\
\cline { 2 - 4 } & $15-11$ & 9 & $9 \%$ \\
\cline { 2 - 4 } & $20-16$ & 11 & $11 \%$ \\
\hline
\end{tabular}


Table (4) Nursing knowledge concerning fatty food

\begin{tabular}{|l|l|l|l|l|l|}
\hline Questionnaires & $\begin{array}{c}\text { Agree } \\
\%\end{array}$ & $\begin{array}{c}\text { Disagree } \\
\%\end{array}$ & $\begin{array}{c}\text { Don't } \\
\text { know\% }\end{array}$ & MS & SN \\
\hline $\begin{array}{l}\text { Non-fat or low fat milk contains less } \\
\text { fat and low calories than whole milk }\end{array}$ & 86 & 7 & 7 & $\mathbf{2 . 7 9}$ & $\mathrm{S}$ \\
\hline $\begin{array}{l}\text { Trans-fats increases LDL cholesterol } \\
\text { levels }\end{array}$ & 64 & 16 & 20 & 2.44 & $\mathrm{~S}$ \\
\hline $\begin{array}{l}\text { Animal fat should be restricted for } \\
\text { diabetes patients }\end{array}$ & 68 & 17 & 15 & 2.72 & $\mathrm{~S}$ \\
\hline $\begin{array}{l}\text { cholesterol should be restricted to 300 } \\
\text { mg daily for diabetes patient }\end{array}$ & 42 & 20 & 38 & 2.04 & $\mathrm{~S}$ \\
\hline $\begin{array}{l}\text { Diabetes and obesity are closely } \\
\text { related }\end{array}$ & 95 & 4 & 1 & 2.94 & $\mathrm{~S}$ \\
\hline $\begin{array}{l}\text { Reducing Calories has importance to } \\
\text { diabetic patients }\end{array}$ & 78 & 11 & 11 & 2.67 & $\mathrm{~S}$ \\
\hline $\begin{array}{l}\text { Animal fat should be restricted in } \\
\text { diabetic patients }\end{array}$ & 81 & 8 & 11 & 2.7 & $\mathrm{~S}$ \\
\hline
\end{tabular}

Table (5) Nursing knowledge concerming carbohydrates

\begin{tabular}{|l|l|l|l|l|l|}
\hline Questioners & Agree & Disagree & $\begin{array}{l}\text { Don } \\
\text { know }\end{array}$ & MS & SN \\
\hline $\begin{array}{l}\text { Diabetes patients should not exclude any } \\
\text { nutrient from their diet }\end{array}$ & 19 & 79 & 2 & 2.17 & $\mathrm{~S}$ \\
\hline $\begin{array}{l}\text { Use total carbohydrates on food labels to } \\
\text { determine amount of carbohydrates per } \\
\text { serving }\end{array}$ & 75 & 12 & 13 & 2.62 & $\mathrm{~S}$ \\
\hline $\begin{array}{l}\text { The total amount of carbohydrates is more } \\
\text { important than the type of carbohydrate }\end{array}$ & 46 & 34 & 20 & 2.26 & $\mathrm{~S}$ \\
\hline $\begin{array}{l}50-60 \% \text { of the daily caloric intake of } \\
\text { diabetics should come from carbohydrates }\end{array}$ & 45 & 19 & 36 & 2.09 & $\mathrm{~S}$ \\
\hline $\begin{array}{l}10-15 \% \text { of the daily caloric intake of } \\
\text { diabetics should come from protein }\end{array}$ & 40 & 18 & 42 & 1.98 & $\mathrm{NS}$ \\
\hline $\begin{array}{l}\text { Starch food such as bread and rice should } \\
\text { be restricted in diabetic patients }\end{array}$ & 84 & 14 & 2 & 2.82 & $\mathrm{~S}$ \\
\hline
\end{tabular}

Another important finding of this study was that over $(60 \%)$ of nurses were able to correctly identify the appropriate initial treatment for hypoglycemia. This is higher than the $(6.5 \%)$ reported by Drass et al., (1989) consistent with the $(62.9 \%)$ reported by (Carney et al., 2010) but lower than the (73\%) reported by Ahmed et al., (Ahmed et al., 2012).
In this study as over (10\%) of the nurses said they will recommend either a piece of cake with icing, 1 cup of milk or a slice of bread for the initial treatment of hypoglycemia, over (10\%) did not know what to do with a patient experiencing hypoglycemia

Nurses' knowledge in this regard requires improvement probably through refresher 
courses. Coexistence of high cholesterol and LDL levels in diabetes patients puts them at a higher risk of developing the metabolic syndrome. As such advising diabetes patients to reduce their intake of fat especially animal fat is very important.

However, the nurses' knowledge in this regard was found poor $(6 \%)$. Even though over $(80 \%)$ of the nurses were able to correctly identify that non-fat or low fat milk was lower in fat and calories than whole milk, while $(20 \%)$ of them did not know that transfats increases plasma LDL cholesterol levels. In furtherance, over (20\%) did not know that animal fat should be restricted for diabetes patients. Also, over (40\%) did not know the recommended daily intake of cholesterol for diabetes patients is the lack of knowledge among the nurses (Schaller and James, 2005).

The study conclude that nurses should be give nutritional courses about the adequacy of nurses knowledge in the nutritional management and the quality of dietary information provided to patients.

\section{References}

Aguiree, F, Brown, A., et al., (2013). IDF diabetes atlas. Ahmed, A., Jabbar, A., et $a l .$, (2012). Diabetes related knowledge among nurses: A multicenter Study in Karachi, Pakistan. BMC Endocrin attitudes and nutrient intakes of nurses working in Kyungnam area. The Korean

Ahmed, A., Jabbar, A., et al., (2012). Diabetes related knowledge among residents and nurses: A multicenter study in Karachi, Pakistan. BMC Endocrine Disorders, 12 (1), 18.

Bantle JP, Wylie-Rosett J, Albright AL, Apovian CM, Clark NG, Franz MJ, Hoogwerf BJ, Lichtenstein AH, MayerDavis E, Mooradian AD, Wheeler ML. (2008) Nutrition recommendations and interventions for diabetes: a position statement of the American Diabetes Association. Diabetes Care. 31 Suppl 1:S61-78.

Carney, T. A. (2010). Knowledge, comfort level and the perceived role of nurses in promoting nutritional management of diabetes. Drexel University.

Drass, J. A., Muir-Nash, J., et al., (1989). Perceived and actual level of knowledge of diabetes mellitus among nurses. Diabetes Care, 12 (5), 351-356.

Evert AB, Boucher JL, Cypress M, Dunbar SA, Franz MJ, Mayer-Davis EJ, Neumiller JJ, Nwankwo R, Verdi CL, Urbanski P, Yancy WS (2013). Nutrition therapy recommendations for the management of adults with diabetes. Jr., American Diabetes Association Diabetes Care; 36 (11):3821-42

Lindseth, G. (1990). Evaluating rural nurses for preparation in implementing $J$ Rural Health. $1990 \mathrm{Jul}$; 6 (3):231-45.

Nelm, M., Sucher, K., et al., (2010). Nutrition therapy and pathophysiology. Cengage Learning. Nutrition interventions. The Journal of Rural Health, 6 (3), (231245).

Schaller, C., and James, E. L. (2005). The nutritional knowledge of Australian nurses. Nurse Education Today, 25 (5), 405-4412.

Scheiderich SD, Freibaum CN, Peterson LM (1983) Registered nurses' knowledge about diabetes mellitus. Diabetes Care; $6(1): 57-61$

Sukhpal K. and Indarjit W (2007). Knowledge of diabetes mellitus amongst nursing students Effect of an intervention Nursing and Midwifery. Research Journal, Vol-3, No. 1.

Victor Mogre, Gloeri A., Dedorah N., and Helene (2015) assessing nurses Knowledge level in the nutritional management. International Journal Africa nursing sciences 3. pp: 40-43 
Warber, J.I., Warber, J.P., Simone, K.A., (2000.) Assessment of general nutrition knowledge of nurse practitioners in
New England. J. Am. Diet. Assoc. 100 (3), (368-370.)

\section{How to cite this article:}

Wasfi Dhahir Abid Ali, Ertihal Thamer Nasir and Abeer Bahlol Mohi. 2018. Study on Nutritional Nurses Knowledge Regarding Diabetes in Basra City Center Hospitals. Int.J.Curr.Microbiol.App.Sci. 7(09): 2255-2260. doi: https://doi.org/10.20546/ijcmas.2018.709.279 